\title{
Study of College English Teaching Based on WeChat Platform
}

\author{
Zhao Xing \\ College of foreign languages, Baoji University of arts and sciences, Baoji 721013, China
}

Keywords: WeChat; college; English teaching

\begin{abstract}
The traditional college English teaching has gradually displayed many defects in terms of teaching methods, modes and concepts, so it urgently needs to be reformed and innovated. The development of information technology and communication technology has provided opportunities and possibilities for the reform of English teaching. Especially, the popularization and application of WeChat has injected fresh blood into the sustainable development of college English teaching. Based on universal problems in present college English teaching, this paper expounds the advantages of the application of WeChat platform to college English teaching, and puts forward the comprehensive strategies for the application of WeChat platform.
\end{abstract}

\section{Introduction}

With the development of information technology and its integration with various fields, worldwide educators in various sections of society are devoted to the application of information technology to the teaching process, hoping to improve the level of educational informationization and modernization. A series of policies and regulations supporting the development of education informationization have also been promulgated in China. For example, the Educational Informationization Ten-year Development Plan (2011-2020) (hereinafter referred to as "Panning") has made specific requirements for the application of information technology in teaching. This suggests that with the constantly advancing educational informatization process in China, the traditional teaching methods can hardly meet the needs of modern classroom teaching. Especially in colleges and universities where the students are active in thinking and have more free time, it is becoming an important subject in the information process of higher education how to cultivate students' autonomous learning ability and innovation ability and to enable the students to make full use of their spare time for study. The extensive use of WeChat, especially the emergence of WeChat official platform, has provided new ideas for the reform and development of college teaching. In this paper, based on the author's practical work experience, college English teaching is taken as an example to study the application of WeChat platform.

\section{Problems in College English Teaching}

There are various problems in present college English course teaching in China. Many experts and scholars have conducted a series of studies on college English teaching. According to the author's summary and investigation, the problems are mainly manifested in the following aspects:

First, the students' language applied ability is not strong, especially in the underdeveloped west areas, "dumb English" and "deaf English" are still problems difficult to overcome. Given this, China Youth News has published a series of articles that discuss the reform of English teaching. There is a popular belief among experts that the existing teaching mode of college English courses is time consuming but inefficient, and teachers and schools have devoted great efforts into the mode, while the teaching efficiency is unsatisfactory, and the students' ability is not very strong. Lagging behind the society's needs, the undergraduates cultivated by the existing teaching system have very low oral communicative competence, and extremely low practical operation ability of English listening, speaking, reading, writing and translating. According to relevant survey results, college English has become a most time-consuming and energy- consuming course. In addition to daily classroom teaching, most undergraduates will spend over 2 hours every day on English learning. As to this, the 
discontent of many students is openly voiced, the students think that they have devoted much time in English learning, thus less time is left for the study of specialized courses. Even if like this, they cannot understand or speak English in real life, but can only do English exercises.

Besides, many students think that their listening and speaking ability is weak, which constitutes a great obstacle for college English learning, so they hope urgently to improve their listening and speaking ability.

Second, there is the problem of "universal application" in the course system of college English, which hinders the students' individualized development and is hard to meet the needs of students' personalized learning. The English proficiency of college students is often varied at admission. Some students have wide vocabulary and poor grammar knowledge, while some other students have strong listening and speaking ability and poor reading ability. Moreover, the regional difference in students' English competence is significant. Students from the south, especially the southeastern coastal areas, are often strong in English comprehensive ability and have obvious capacity superiority in listening and speaking. The difference in oral expression ability between individual students is also significant. Some non-English major students prefer English oral communication, and can even defeat English major students in speech contest and win a place, while some other students are even unable to know all the basic phonetic symbols. In view of this, it is difficult for classroom teaching to achieve differential teaching, while the extracurricular learning lacks hierarchical and targeted effective guidance for the students.

Finally, the examination stress from CET-4 and CET-6 has hindered the cultivation of students' language applied ability. Shou-Ren Wang, vice chairman of China English Language Education Association and president of the Foreign Language School of Nanjing University, proposed that China's English teaching generally has the problem of "time-consuming"and"low efficiency", it attaches importance to exam-oriented education while neglecting the cultivation of ability of using English. Some teachers have inadequate understanding of CET-4 and CET-6, and excessively pursue the passing rate and the dealing with exams. Those teachers teach for exams, and their students study for exams, in the process of teaching, those teachers neglect the improvement of the students' practical English ability, the extracurricular study also focuses on repeated exercises for CET-4 and CET-6, and even excessive assignments tactic is used in order to pass the exams. All these acts have made English learning fall into a monotonous and tedious vicious circle, and can not develop English learning into an interest, as a result, many students no longer learn English after passing CET-4 and CET-6. Moreover, although oral language test is set in CET-4 and CET-6, it is only used as a reference index and does not affect the total points of the exams, given this, most students did not participate in the oral language test, and they even do not know the existence of the test. In order to cope with the exams, students will make light of the training of oral communicative competence to a higher degree.

\section{The Advantages of WeChat Application in College English Teaching}

At present, various problems existing in college English teaching have led to the gap between the integral level of college English teaching and the expected goal. Hence, it is necessary to promote the further improvement of college English teaching through some advanced and epochal techniques or methods, and the application of WeChat platform can exactly make up for the deficiencies of some traditional teachings.

\subsection{Rich functions to stimulate students' learning interest}

WeChat has integrated multiple functions, such as texts, audios, images and groups, into one. It can effectively make up for the defect of simplex teaching means in traditional classroom teaching, and its abundant and various teaching materials as well as teaching activities of different forms can effectively mobilize students' learning initiative. WeChat's voice communicative function can help students to break away from the embarrassment in face-to-face communication, and gradually change students from "dare to speak"to "love to speak".

The diversity and extensibility of WeChat functions is an essential condition for WeChat to 
support college English teaching. Through secondary development, various modules suitable for English teaching can be obtained. Meanwhile, the instant communication function of WeChat meets the daily habits of college students and can better arouse students' interest in learning English. In addition, various learning materials and instant communication can help students to strengthen their understanding of the classroom teaching content, change students into subjects of classroom teaching, and give full play to students' subjective role, thus making the students further meet the requirements in the Course Requirement.

\subsection{Instant communication to enhance emotional communication between teachers and students}

In the process of college English teaching, it is difficult for students to communicate face-to-face with teachers except for in school hours and fixed tutoring time. Thus, the students can hardly feed their confusions generated in the process of English learning back to their teachers timely and effectively or communicate with the teachers, thereby affecting the teaching effect. Sending instant text and voice messages via WeChat can effectively make up for the deficiency in communication after class between teachers and students. With interchangeable questions and answers, teachers can learn the points they did not explain explicitly in the teaching, students' confusions can be resolved, and the communication can make the relationship between teachers and students closer. Modern teaching theory proposes that teaching process is a psychological activities-based unification of emotional process and cognitive process. In English teaching, the participation of teacher-student emotions is conducive to the development of students' non-intellectual factors, and directly affects classroom efficiency. Benign and positive teacher-student emotion is beneficial to the achievement of the so-called realm of "trust your master, follow his way" in the ancient saying, in other words, teachers love and place hope on their students, the students are contented psychologically and spiritually, they love and respect their teachers, they are willing to receive education, furthermore, they internalize the teachers' requirements into their own needs and make unremitting efforts.

\subsection{Convenient resource-push to promote students' extracurricular learning}

Students can use WeChat to exchange their learning experience whenever necessary. The functions of WeChat group and Circle of Friends have provided efficient support for class and group communications, students can to the fullest exchange their learning experience in WeChat group and discuss on some topics or resources in the Circle of Friends. The space-time nonrestriction feature of WeChat has changed the traditional classroom teaching mode of college English. As a result, college English teaching no longer focuses on the 40-minute class time, more learning exchanges are transferred to extracurricular time, students can make learning plans and arrange learning contents according to their physical truth. For example, by sending voice messages via WeChat, students can conduct adequate communications on classroom learning contents after school, and teachers can push materials for extended reading to supplement the textbook content via WeChat. Besides, students can also exercise their writing and grammar application competence during discussion and use WeChat voice function to improve their listening and oral communicative levels. Furthermore, students can upload homework to their teachers on WeChat public platform, and by reviewing the students' homework on the platform, teachers can summarize the problems in their teaching, so as to improve their understanding of the students' learning effect, to better adjust the teaching plan and to provide targeted tutorship. In addition, WeChat can transform English in students' textbook into English for practical application, thus improving students' English application ability.

\subsection{Secondary development of the public platform to meet the actual needs in class.}

College English course itself has distinctive features, so in the secondary development of WeChat public platform, various functions can be customized according to the course features. For example, the sophomore students majoring in computer of Suzhou University of Science and Technology designed a set of simple system for English classroom interaction using WeChat public platform, which has introduced the instantaneity and property of participation of social contacts into 
the classroom. The entire interactive system consists of three parts, including students' WeChat terminal, teachers' mobile phone control terminal and the classroom large screen. The three parts interact with each other using the WeChat official account "mobile language learning". During the whole class, the students can use WeChat to answer questions, participate in group discussions, submit assignments, and interact with teachers, the teachers can use the mobile phone control terminal to check the students' learning situation and control the rhythm of the whole interactive process, and the large screen can link with and display the interaction between teachers and students. Of course, the above is only one way of using WeChat public platform to support classroom teaching. With the gradually mature secondary development technology and the constantly lowering threshold, it is believed that more teachers will join the ranks of the secondary development and customize unique tools suitable for themselves according to the course features.

\section{Key Issues on WeChat Application in College English Teaching}

\subsection{Effective teaching design}

Teaching design is the key factor of deciding whether a lesson can be successful or not. Therefore, in the process of teaching using WeChat, different teaching activities should be designed according to the content of the teaching courses, particular stress should be laid on the application of WeChat functions and targeted secondary development should be carried out. For example, the listening and speaking teaching of college English mainly adopts some WeChat functions related to voice communication, the design of activities is based on communication, exercises and testing, and it is appropriate to carry out activities such as discussions, exchanges of works and mutual evaluation in the teaching of reading and writing, which will more frequently use functions such as sharing in Circle of Friends, comments, public platform graphic message push and WeChat group.

At the same time, the activity design should give more consideration to the difference in students' individual learning level, select targeted teaching strategies as far as possible, and find the equilibrium point between the teaching content and the individual difference of learners, so as to meet the needs of more learners to the greatest extent.

\subsection{Reasonable division of the learning groups}

The division of learning groups should be provided with a theoretical basis, and be reasonably carried out according to the practical situation. The selection of the number of members and the organizers should be prudent. In listening and speaking teaching, the number of group members should not be too many, so as to avoid mutual interference of information. In reading teaching, the number of group members can be appropriately more than that in listening and speaking teaching, so that each can air his own views and the spark of thought is more likely to occur by collision. But some activities need to be conducted by organizers. In the case of a lot of groups, teachers can easily have their hands full. At this time, some students with strong ability can be selected to help carry out the activities. Meanwhile, in some activities allowing for free group discussions, there is no need to appoint organizers or group leaders, so as to prevent interdependence among the students or formalistic discussions.

\subsection{Timely guidance for students}

First, students will inevitably have numerous confusions in the process of learning, especially when new technology is introduced to the process of teaching, some students may hold a suspicious or even repulsive attitude towards the technology. At this time, the teachers need to perform timely explanation and guidance, so that the students can gradually accept the new teaching tools. Second, when students feel helpless and have no way to start in group activities, guidance should be given to them timely, thus ensuring smooth development of the activities. Finally, if the students blindly use WeChat for chat and entertainment, while ignoring extracurricular learning, they should be appropriately reminded and guided to use WeChat for learning in addition to leisure and entertainment. 


\section{References}

[1] Hu Xiaojuan. Application exploration of WeChat software in college English teaching [J]. Journal of Jinan Vocational College, 2014, (1).

[2] Zhang Kexin. Research of college English writing teaching based on WeChat [D] Harbin University of Science and Technology, 2017.

[3] Zhu Xuewei, Zhu Yu, Xu Xiaoli. Research and design of mobile learning platform supported by WeChat [J]. China Distance Education, 2014, (4). 